Meta

Journal des traducteurs

Translators' Journal

\title{
Environmental Law Dictionary: from Theory to Practice
}

\section{Maria Da Graça Krieger, Anna Maria Becker Maciel, Cleci R. Bevilacqua, Maria Lucia Lorenci, Teresinha O. Favero et Marília R. De Oliveira}

Volume 41, numéro 2, juin 1996

Traduction et terminologie au Brésil

Translation and Terminology in Brazil

URI : https://id.erudit.org/iderudit/003351ar

DOI : https://doi.org/10.7202/003351ar

Aller au sommaire du numéro

Éditeur(s)

Les Presses de l'Université de Montréal

ISSN

0026-0452 (imprimé)

1492-1421 (numérique)

Découvrir la revue

Citer cet article

Krieger, M. D. G., Becker Maciel, A. M., Bevilacqua, C. R., Lorenci, M. L., Favero, T. O. \& De Oliveira, M. R. (1996). Environmental Law Dictionary: from Theory to Practice. Meta, 41(2), 259-264. https://doi.org/10.7202/003351ar

\section{Résumé de l'article}

Cet article examine certains problèmes rencontrés lors de l'élaboration d'un dictionnaire de termes juridiques brésiliens des sciences de l'environnement et propose quelques solutions pour y remédier. Les principales difficultés rencontrées découlent du croisement de deux domaines, chacun ayant ses propres exigences. On montre comment, pour parvenir à des solutions acceptables, il a fallu prendre des décisions qui ont affecté la structure même du dictionnaire.
Tous droits réservés @ Les Presses de l'Université de Montréal, 1996

Ce document est protégé par la loi sur le droit d'auteur. L'utilisation des services d'Érudit (y compris la reproduction) est assujettie à sa politique d'utilisation que vous pouvez consulter en ligne.

https://apropos.erudit.org/fr/usagers/politique-dutilisation/ 


\title{
ENVIRONMENTAL LAW DICTIONARY: FROM THEORY TO PRACTICE
}

\author{
Maria Da Graça Krieger, anna Maria Becker Maciel, Cleci R. Bevilacqua, \\ Maria Lucia Lorenci, Teresinha O. Favero, Marília R. De Oliveira ${ }^{1}$ \\ Institute of Letters, Federal University of Rio Grande do Sul, Porto Alegre, RS, Brazil
}

\begin{abstract}
Résumé
Cet article examine certains problèmes rencontrés lors de l'élaboration d'un dictionnaire de termes juridiques brésiliens des sciences de l'environnement et propose quelques solutions pour y remédier. Les principales difficultés rencontrées découlent du croisement de deux domaines, chacun ayant ses propres exigences. On montre comment, pour parvenir à des solutions acceptables, il a fallu prendre des décisions qui ont affecté la structure même du dictionnaire.
\end{abstract}

\begin{abstract}
This paper describes some of the problems encountered in compiling a dictionary of Brazilian environmental law terms and proposed solutions. The major difficulties stemmed from the overlapping of two distinct areas (environmental science and law), each with its own specific requirements. To overcome these hurdles, decisions had to be made which affected the very structure of the dictionary itself.
\end{abstract}

\section{BACKGROUND}

The publication of a dictionary of environmental law terms is the main purpose of the terminological research project Projeto Terminologico Cone Sul (TERMISUL) at the Federal University of Rio Grande do Sul, Brazil. The decision to carry out this work is not fortuitous, but based on political and cultural imperatives: firstly, as an instrument of univocal communication aimed at integrating the Latin American South Cone; secondly, as the basis for a termbank for a future Latin American terminological network.

Over the last decade, the South Cone countries, namely Argentina, Brazil, Uruguay and Paraguay, have been implementing an economic and cultural integration project leading to a common market Mercado Comum do Cone Sul (Mercosul) to be fully established in 1995.

The South Cone integration is a fundamental proposal since it involves countries with a similar economic, social and cultural environment and stimulates the development of local potentialities. In this context, the common dominium of terminologies will no doubt facilitate mutual understanding, especially if access to technical and scientific language in Spanish and Portuguese is provided.

Spanish is spoken all over South America except in Brazil, where Portuguese is the vernacular. Though both languages, Portuguese and Spanish, share a common origin and similarities, different phonological, morphosyntactic and semantic features tend to hinder communication.

Bilingualism in international policy requires precise definitions of terms and, therefore, demands reliable terminological reference aids. Such instruments, especially in Brazilian Portuguese and Latin American Spanish are rarely found. 
Furthermore, by sharing common boundaries with neighbouring territories, the South Cone countries are deeply concerned with environmental matters. Even though a number of ecological glossaries and dictionaries have been recently published, a multilingual work compiling environmental law terms has not been issued up to now.

Within this framework, research in the field of the terminology of the environment used in Brazilian legislation has been undertaken. Although the basic requirements of field delimitation, term selection and data compilation have already been fulfilled following Rondeau (1984) and Dubuc (1992), the actual everyday application has posed a variety of problems demanding factual solutions. The purpose of this paper is to describe some of these problems and to consider ways of solving them.

The challenges, faced along the procedural stages of this research, stem from the intersection of the two particular domains examined, namely, environmental science and law, which have their own characteristics and methodologies. To overcome these obstacles, decisions had to be made concerning the structure of the dictionary.

\section{PURPOSE AND SCOPE}

From the outset of the project, the dictionary was thought to cover the entire range of Latin American environmental law terminology. Because of the magnitude of the field, however, the task proved to be unfeasible. Moreover, the reliability of the equivalence of terms covering concepts from different legal systems added to the difficulty. A compromise, therefore, had to be reached: a dictionary of Brazilian environmental law terms with linguistic equivalents in Spanish and English seemed to be the best option.

The selection of sources took three aspects into consideration: the wide range of the interdisciplinary field - law and environment; the different levels of Brazilian legislation (federal, state and municipal); and the target user (general public). The broad range of the domain encompassing two disciplines of dissimilar nature and scope has led to a continuous reassessment of the theoretical and methodological principles adopted and their practical application.

Federal legislation was chosen as the primary source of the corpus. Federal laws rule national life in a country made up of a great many states organized in a variety of municipalities, each one having local legislation.

Laws are usually synthetic texts, and their regulatory and sanctioning nature do not offer semantically rich contexts to provide satisfactory definitions. The polysemous nature of terms occurring with different meanings in different legal contexts creates ambiguities. Further documentation and consultation with specialists have therefore been needed to gather additional data to enable the terminologist to build a juridically accurate and linguistically satisfactory definition (Gémar 1986: 444).

The recent familiarity of the general public with environmental issues, on the one hand, and the newness of the area and the consequent plethora of new terms and concepts, on the other, account for the option of the target user: the layperson. Although this person does not have a deep knowledge either of environmental science or law, he or she must use a precise terminology for contractual relations established at national and international levels.

Furthermore, the dictionary is also intended to offer a reliable and helpful terminological instrument to the legislator when discussing new aspects of environmental law.

Last but not least, by providing English and Spanish equivalents of Portuguese environmental law terms, the dictionary is supposed to contribute to the integration process of Latin America. Finally, the choice of English as a third language is fully justified by its role as an international vehicular language or lingua franca (Sager 1990: 216). 


\section{LEXICAL SELECTION}

Terminological work usually seems to be a simple task to the layperson and even to the inexperienced researcher: once the domain, target user and source texts have been carefully chosen, term selection is supposed to occur smoothly and almost automatically. Yet, experience shows that compiling a nomenclature of any scientific and/or technological field is a never-ending, time-consuming, complex task requiring regular updating.

Two major principles have been established to guide term selection; one is semantic in nature and the other pragmatic.

The first principle, which is based on the linguistic assumption that a term is a sign with two levels - expression and content - favours the latter level rather than the former.

Two guidelines have been derived from this principle. First, the term should be selected based on the signified, not the signifier. Second, the term should have semantic traits other than those of its signification in the general language.

A number of unexpected problems arose during the application of these guidelines. The boundaries between the lexicon of general language and thematic language do not appear so clear-cut. Consequently, the exclusive principle of the term, although a terminological ideal, does not correspond to the actual use of language.

Moreover, since one of the two domains examined here, the environment, is a developing branch of various sciences, it does not have a particular terminology of its own. In fact, environmental terminology usually stems from a wide range of related fields, such as biology, botany, ecology, zoology, to name but a few, and the general language. To this hybrid composition, a high degree of popularisation is added. Thus it can be said that environmental science is still in an early stage of vocabulary development and lacks an autonomous terminological statute.

Environmental terminology usually appears as complex lexemes, seldom with consolidated lexical cohesion - another common feature of an early stage of linguistic development. In our corpus, an average rate of one complex lexeme for every six single lexeme was observed. Neologisms and new complex lexemes in constant development reveal a high degree of lexical productivity.

Concerning the pragmatic criteria for term selection, we established two priorities. First, the importance and pertinence of a term in the area take precedence over its frequency. Second, the needs and wants of the lay user are favoured over all academic concerns.

As for the first aspect, it is important to point out that the criteria used for term selection in lexicography differ from those in terminography. While frequency is an important element of the former, it does not play a decisive role in the latter. Some terms, though not frequent, are highly representative of the discursive universe of the domain and, as such, are absolutely essential to communication, and must, therefore, be selected (Auger et al. 1988: 32).

As is often the case, the initial criteria soon proved to be insufficient. A vast and diffuse environmental terminology emerged from the legal texts, indicating the existence of a domain other than environment or law. It was then thought that new selection criteria should, perhaps, be applied to this third domain permeating environmental legislation.

It was evident that despite their frequent presence in legal texts, traditional environmental subdomains do not shape the environmental law terminology. The same is also true of the conventional subdomains of law, despite the preeminence of regulatory purposes in legislation.

The particular terminology seemed to constitute a specific discourse. Such a configuration led to a questioning of the principle that any term relating either to the environ- 
ment or the law occurring in legislation should be integrated into the environmental law terminology. Consequently, the need for systematizing these terms in a structured framework was strongly felt. A hierarchy of concepts allowing for the identification of terms within a conceptual system appeared to be present.

From these findings, it was suggested that, if a process of junction between two sciences occured, a new discursive statute with its own terminology - that is, its own nomenclature - would be created. The nomenclature constitutes the hard core of fundamental concepts particular to a domain. The discoursive features of the so-called special languages stem from this core. (Gémar 1991: 275). Despite the presence of concurrent elements, the new terminology is not circumscribed to any of the original domains, but constitutes another domain.

In sum, since it is not a mere juxtaposition that is taking place, the new terminology cannot be compiled simply on the basis of the terms of the subdomains that traditionally make up the areas involved. Otherwise the resulting inventory risks being fragmented and inconsistent. Although the concurrence is maintained, new terms are coined giving new dimensions to notions and suggesting other domains.

It follows from this fact that the practical-theoretical perspective requires serious consideration of the epistemology of the sciences being compiled. The identification of a categorial framework cannot be successfully achieved before the epistemologic nature of the object is studied and understood.

\section{CATEGORIZATION}

In light of the evidence gathered, the investigation of the nature of the terms was carried out by reassessing the previous analysis of the corpus. This reanalysis helped us identify the terms and their particular positions within their respective areas, and generated the categorization discussed below.

Before going any further, a remark should be made about the nature of the Brazilian legal system. In Brazil, as in other Latin American countries, the legal system is still substantially Roman, but has been influenced by Germanic and Napoleonic institutions. It rests mainly on Civil Law as opposed to Commnon Law. This remark is important since it justifies the following taxonomy:

\section{TERMS OF JURIDICAL DEFINITION \\ 1.1 Terms of juridical essence \\ 1.2 Legal terms \\ 1.2.1 Fiction \\ 1.2.2 Policy instruments}

\section{TERMS IMPLICATED BY THE LAW}

1 TERMS OF JURIDICAL DEFINITION - terms designating notions drawn from the law; for example, crime contra o meio ambiente (crime against the environment); regime de permissão de lavras garimpeiras (valuable or prospecting permission regime). The headword of these terms denotes an authentic juridical concept. More accurate investigation eventually led to the identification of features distinguishing two subgroups within this group: terms of juridical essence and legal terms.

While terms of juridical essence have already been defined by preexisting law, therefore, to the environmental laws, the legal terms can be said to be law-born since their origin comes from the promulgation of the law. Subsequently, this last group, legal terms, was broken down into two subcategories: fiction and policy instruments. 
The first subcategory, termed fiction in the context of this systematization, usually comprises general language phrases referring to objects from the natural world which are given new semantic traits when included in the legislation - for example, áreas de proteçâo ambiental (environmental protection areas) and sitio de interesse ecológico (site of ecological interest).

The second subcategory was named policy instruments. It consists of terms referring to legally designed mechanisms used as the basis for decisions concerning environmental protection. Examples of such terms are Relatório de impacto ambiental (RIMA) (environmental impact report (EIR)) and plano nacional de gerenciamento costeiro (PNGC) (national plan of coastal management).

2 TERMS IMPLICATED BY THE LAW - terms which do not cover notions derived from the law, but rather designate those notions issued from a range of sciences covering the environmental domain - for example, biodiversidade (biodiversity), desenvolvimento sustentável (sustainable development), camada de ozônio (ozone layer), poluição ambiental, (environmental pollution) and agrotóxicos, (pesticides).

In this case, it is not unusual for the law to add a peculiar connotation to a term by making it distinctive from the others, or even by isolating a particular aspect of its reality. In such cases, the semantic field of the term is not completely covered and the term is said to have legal limitations. It is not unusual for the phrase para os efeitos desta lei (to the effect of this law), which circumscribes a notion to more narrowly defined limits, to appear.

\section{FINAL CONSIDERATIONS}

The taxonomy revealed two broad categories of terms and levels of subcategories drawn from the terminological structure of a domain proper identified as a discoursive object. The categorial framework devised in the case examined here made it possible to identify the specific domain environmental law which, by presenting its own discoursive statute, proved to be a more complex structure than the sum of pre-existing domains. Consequently, this categorization has been highly instrumental in the lexical-selection and decision-making processes related to the definition of the overall nomenclature of the dictionary.

In addition, by recognizing the nature of the terms, the taxonomy allowed us to view the terms of the two subgroups, fiction and policy instruments, as the most genuine representatives of environmental law terminology. In fact, these terms were selected by the legislator to cover particular notions created for environmental purposes. This emphasizes the idea that legislators are the creators of terminological definitions par excellence, since they have the power to assign a term to a notion they themselves gave birth to (Bessé 1990: 254).

Nevertheless, this ideal picture of the exclusive creation of terms within a particular scientific field is not the rule because, most often, general and special languages overlap. Otherwise, the task of collecting terminologies would be simplified and rather straightforward. Therefore, terminological research may be viewed as a dynamic quest for scientific improvement, forever shuttling between theory and practice given the many facets of the nature of the empirical object studied.

Notes

1. Research assistant student grant of CNPq - Conselho Nacional de Pesquisa e Desenvolvimento (National Research and Development Council). 


\section{REFERENCES}

AUGER, Pierre et al. (1988): Méthodologie de la recherche terminologique, Québec, Office de la langue française, Études, recherches et documentation, $77 \mathrm{p}$.

BESSÉ, Bruno de (1990): "La définition terminologique", Chaurand, J. et F. Maziere (dir.), La définition, Paris, Larousse, $334 \mathrm{p}$.

DUBUC, Robert (1992): Manuel pratique de terminologie, Québec, Linguatec, 144 p.

GÉMAR, Jean-Claude (1986): "Jurilinguistique et lexicographie. Une première canadienne : le Dictionnaire de droit privê"', Les cahiers de droit, 27-2, juin, pp. 437-461.

GÉMAR, Jean-Claude (1991): "Terminologie, langue et discours juridique. Sens et signification du langage du droit", Meta, juin, 36-2, pp. 275-287.

RONDEAU, Guy (1984): Introduction à la terminologie, Québec, Gaétan Morin, 227 p.

SAGER, Juan C. (1990): A Practical Course in Terminology Processing, Amsterdam, John Benjamins, 254 p. 